\title{
Influences of forested and grassland vegetation on Late Quaternary ecosystem development as recorded in lacustrine sediments
}

\author{
Kendra K. McLauchlan $\mathrm{a}^{*}$ \\ Ioan Lascu b,c* \\ Emily Mellicant a \\ Robert J. Scharping $\mathrm{a}^{\wedge}$ \\ Joseph J. Williams d \\ a Department of Geography, Kansas State University, Manhattan KS 66506 U.S.A. \\ b Department of Mineral Sciences, National Museum of Natural History, Smithsonian \\ Institution, Washington, DC 20560, U.S.A. \\ c Department of Earth Sciences, University of Cambridge, Downing Street, \\ Cambridge, CB2 3EQ, U.K. \\ d Department of Geography, Oxford Brookes University, Oxford, U.K. \\ *corresponding author \\ ^ current address: Department of Cell Biology, Microbiology and Molecular Biology, \\ University of South Florida, Tampa, FL U.S.A.
}

keywords: Holocene; Paleolimnology; North America; Sedimentology; Lakes;

Inorganic geochemistry; Vegetation dynamics; Weathering

\begin{abstract}
Geosphere-biosphere interactions are ubiquitous features of the Earth surface, yet the development of interactions between newly-exposed lithologic surfaces and colonizing plants during primary succession after glaciation are lacking temporal detail. To assess the nature, rate, and magnitude of vegetation influence on parent material and sediment delivery, we analyzed ecosystem and geochemical proxies from lacustrine sediment cores at a grassland site and a forested site in the northern U.S. Over time, terrigenous inputs declined at both sites, with increasing amounts of organic inputs toward present. The similarities between sites were striking given that the grassland sequence began in the Early Holocene, and the forested sequence began after the Last Glacial Maximum. Multiple mechanisms of chemical weathering, hydrologic transport, and changes in source material potentially contribute to this pattern. Although there were strong links between vegetation composition and nitrogen cycling at each site, it appears that changes in forest type, or from oak woodland to grassland did not exert a large influence on elemental $(\mathrm{K}, \mathrm{Ti}, \mathrm{Si}, \mathrm{Ca}, \mathrm{Fe}$, $\mathrm{Mn}, \mathrm{S}$ ) abundance in the sedimentary sequences. Rather, other factors in the catchment-lake system determined the temporal sequence of elemental abundance.
\end{abstract}

\section{Introduction}

One of the fundamental relationships within Earth systems is the interaction

43 between the geosphere and the biosphere. The role of terrestrial plants in shaping

44 newly formed landscapes (i.e. primary succession) has been studied after glacial

45 retreat (Buma et al. 2017), volcanic eruptions (Cutler et al. 2008), and mass 
movement (Colombaroli and Gavin 2010). Most Earth surfaces are considered to undergo relatively slow rock weathering processes. These processes are dominated by climatic factors, but vegetation also influences weathering (Pawlik et al., 2016) and vice versa (Hahm et al., 2014). The nature of the geosphere-biosphere relationship, and its regulators in space and time, vary across various climatic, geomorphic, tectonic, and biotic settings (Porder, 2014). Here, we focus on the biotic setting, comparing the pace and nature of ecosystem development between two major vegetation types-forest and grassland - to improve our understanding of the relative effect of biota on the geochemical composition of sediments over millennial timescales (Jenny, 1941).

To understand landscape development over time, we are often limited to comparing Earth-surface features to source rock material. While this can give some indication of how plants may have interacted with rock on timescales of $10^{5}$ or $10^{6}$ years, the intermediate steps, rates, and controls of geosphere-biosphere processes are

61 unknown using this approach. Nonetheless, chronosequence studies of primary

62 succession have demonstrated, broadly, how ecosystems change over time. As 63 primary successional stages develop, there is generally a temporal sequence of 64 biogeochemical changes such as base cation mineral weathering, organic matter 65 accumulation from the terrestrial biosphere, increases in plant-available nitrogen, 66 and decreases in phosphorus (Laliberte et al., 2012; Wardle et al., 2004). However, 67 characterizations of these early stages lack high temporal detail. In particular, we 68 may be missing important system behavior such as tipping points and pedogenic 69 thresholds (Vitousek and Chadwick, 2013).

Early postglacial successional processes can be reconstructed by studying geochemical records of rock-plant interactions in continuously-deposited lacustrine sedimentary records (Mackereth 1966, Pennington et al. 1972, Engstrom and

74 Hansen 1985). These records provide information on a finer scale $(<17,000 \mathrm{yBP})$

75 than is possible in temperate chronosequences. Measuring elemental concentrations

76 in sedimentary sequences has a long history (Likens, 1985; Willis et al., 1997), but

77 because of the proxy nature of these records, interpretation is aided by a multitude

78 of other parameters describing the properties of these systems (Kylander et al.,

79 2011). Of particular importance are proxies of transport processes from the

80 catchment to the sediment. These dynamic processes are a function of climatic

81 changes, lithological variability, and differences in vegetation cover between

82 grassland and forested catchments. Through multi-proxy investigation, sedimentary

83 sequences have begun to yield unique information about early ecosystem processes.

84 For example, important information about $P$ cycling can be obtained from studying

85 the chemical weathering of the phosphate mineral apatite early in catchment

86 development (Boyle 2007, Norton et al. 2011).

87

88 There are several potential mechanisms for how terrestrial vegetation could 89 determine trajectories of biogeochemical change on centennial to millennial 90 timescales, as seen in Holocene sedimentary records. First, vegetation composition

91 can influence chemical weathering rates. There are examples of organic acids 
produced by coniferous vegetation speeding ecosystem acidification (Ford 1990) and even leading to podsolization during the Holocene (Davis et al., 2006).

Conversely, removal of trees has been demonstrated to cause an increase in soil $\mathrm{pH}$

(Bradshaw et al., 2005). Second, the degree of vegetation cover (primary

productivity) can affect hydrologic pathways and physical weathering. Large-scale

changes from grassland to forests between stadials and interstadials during the Last Glacial, with different rates of productivity, led to differences in weathering product delivery to a depositional basin (Kylander et al., 2011). Finally, there are also potential feedbacks between fire regimes and geochemistry. In lodgepole pine forests of the western U.S., loss of nitrogen and base cations has occurred over the past 4,000 years with repeated fire (Dunnette et al., 2014; Leys, 2016). While fire events and plant cover were significantly related at Thyl Lake in the French Alps, soil processes were primarily linked to vegetation composition, and secondarily to changes in fire regime (Mourier et al., 2010).

To assess rates, patterns, and mechanisms of ecosystem development after glacial retreat, we compared two sedimentary sequences in the upper Midwestern U.S. from a grassland site and a forested site. Our three main questions were:

1) How did source material change over the sedimentary sequences?

2) What were the patterns of nutrients, especially limiting nutrients such as nitrogen, potassium, calcium, and magnesium, during Holocene ecosystem development?

3) Did the terrestrial biosphere determine the trajectory of elemental change at each site?

\section{Methods}

\subsection{Study sites}

Fox Lake is located in southern Minnesota, U.S.A., has a surface area of $3.85 \mathrm{~km}^{2}$, and a maximum water depth of $6 \mathrm{~m}$. The lake was formed during the retreat of the Des Moines Lobe of the Laurentide Ice Sheet at the end of the last glaciation about 12,000 years ago (Maher, 1982(Lusardi et al. 2011)). Fox Lake is approximately 10 $\mathrm{km}$ from the southernmost extent of the Des Moines Lobe, but the timing and path of deglaciation are not entirely clear in this region. The catchment parent material is calcareous glacial till, and lake water geochemistry is dominated by catchment input rather than precipitation-evaporation dynamics (Gorham et al. 1983). There is one small inlet stream on the west side of the lake. Soils surrounding Fox Lake are a mix of Udols and Aquolls-poor to well-drained clay loams formed from calcareous tills - and are often deep ( $>2 \mathrm{~m}$ ) (USDA NRCS).

Devils Lake is located in southern Wisconsin, has a surface area of $1.53 \mathrm{~km}^{2}$, and a maximum depth of $14 \mathrm{~m}$. Catchment parent material is primarily hematite-rich quartzite, as well as glacial till deposited in moraines from the Green Bay Lobe at the end of the last glacial period, ca. 18,500 cal yBP (Attig et al. 2011). Soils in this area are thin (0.5-1 m) Udalfs-moderately well-drained stony and cobbly silt loams formed from a mixture of loess and quartzite bedrock (USDA NCRS). Devils Lake is 
located just to the south of the maximum extent of the Laurentide Ice Sheet. The catchment of Devils Lake has areas of quartzite cliffs and the geology is considerably different than Fox Lake and therefore these two sites capture a wide range of weathering products to lakes.

The two study sites are $\sim 480 \mathrm{~km}$ apart (Fig. 1). The sites were chosen due to their positions relative to the furthest advance of the Laurentide Ice Sheet and dominant vegetation cover during the Holocene. At the time of Euro-American settlement (mid-1800s), Fox Lake was tallgrass prairie characterized by warm-season grass species such as Andropogon gerardii, Sorghastrum nutans, and Schizachyrium scoparium (Küchler 1964). Today, the Fox Lake catchment is dominated by agriculture. In contrast, Devils Lake is surrounded by mixed deciduous-coniferous forest including the conifer Pinus strobus and deciduous components of Quercus rubra, Quercus alba, and Acer rubrum, and herbaceous savanna understory vegetation. Modern vegetation between the two sites likely varies due to differences in precipitation. Devils Lake on average receives $914-940 \mathrm{~mm}$ of annual 154 precipitation, while Fox Lake receives 762-812 mm of annual precipitation (NOAA 155 NWS).

In February 2012, we obtained sediment cores from both Devils Lake and Fox Lake 158 using piston corers. The Fox Lake sediment core was 9.3 meters long and the Devils 159 Lake sediment core was $10.4 \mathrm{~m}$ long.

A previous study of Fox Lake established a radiocarbon-based chronology as well as the vegetation and fire history (Commerford et al. 2016). The same sediment cores were used to measure the proxies described in the current manuscript. Previously, vegetation history reconstructed by pollen analysis from 9,300 cal yBP indicates that Fox Lake has been a grassland site since near the beginning of the record, with only one slight change from oak forest to grassland at 8,200 cal yBP (Commerford et al. 2016). The oak forest vegetation is characterized by high amounts of Quercus pollen (an arboreal pollen type), and the grassland vegetation is characterized by high amounts of non-arboreal pollen types such as Poaceae, Ambrosia, and Artemisia. Thus, for this study we used the \% arboreal pollen to capture this vegetation transition at Fox Lake. The lithostratigraphy for Fox Lake is consistently characterized by dark brown, high organic matter sediment throughout the core. Five zones (F1-F5) were determined with constrained hierarchical cluster analysis using changes in magnetic susceptibility (Commerford et al. 2016).

Details of the lithology, radiocarbon chronology, fire history, and geochemical proxy records of Devils Lake are also described previously (Williams et al. 2015). The same sediment cores were used to measure the proxies described in the current manuscript. Devils Lake has a much longer record than Fox Lake, beginning at 17,000 cal yBP (Williams et al. 2015), and captures three types of forest: spruce, pine, and hardwood (Maher 1982). The detailed pollen stratigraphy with three forest types was established by Maher (1982) and a robust chronology was established by Williams et al. (2015) with input from Grimm et al. (2009). The 
changes in vegetation from coniferous to hardwood forest types are characterized by changes in spruce pollen (Picea), pollen from hardwood trees (Quercus and Ulmus) and grass pollen (Poaceae). The lithostratigraphy of Devils Lake varies throughout the core, with five main units. Five zones (D1-D5) were delineated based on sediment appearance, composition, and mineralogy (Williams et al., 2015).

The two study sites differ in multiple ways-they cover different time periods (one starting in the Late-glacial and the other in the early Holocene), are situated in different geologic terrains, and were analyzed for a different suite of sedimentary proxies - but chiefly provide an important contrast in dominant vegetation type and the degree of vegetation change during their respective records. To put the lithologic, pollen, and sedimentological changes for each lake in context, we use the stratigraphic zones previously delineated and published for each lake [Fox Lake in Commerford et al. 2016 and Devils Lake in Williams et al. 2015]. The same sediment cores were used to establish the stratigraphic zones and also for the new analyses presented in this manuscript for both Fox Lake and Devils Lake.

\subsection{Micro $X$-ray fluorescence $(\mu-X R F)$ core scanning}

All sections of the Devils Lake and Fox Lake sediment cores were scanned using an Itrax XRF core scanner (Cox Analytical Systems, Gothenburg, Sweden) at the LacCore X-ray Fluorescence Laboratory housed at the University of Minnesota Duluth Large Lakes Observatory. This instrument produces an optical RBG digital image, a microradiographic digital image, and count data for most elements from aluminum (atomic number 13) to uranium (92). XRF scans were performed using a molybdenum tube set at $30 \mathrm{kV}$ and $25 \mathrm{~mA}$ with a dwell time of $60 \mathrm{~s}$ and a step size of $10 \mu \mathrm{m}$. The Fox Lake data were reduced by averaging to $1 \mathrm{~cm}$, while the Devils Lake data were averaged to $0.1 \mathrm{~cm}$ and then smoothed using a 10-point running mean. The raw count data is expressed as counts second ${ }^{-1}$ (cps).

For elements with sufficient counts, we divided the elemental counts by molybdenum coherence (MoCoh) values for each measured interval to account for variation among analytical time periods in the characteristics of the Mo tube. A centered log ratio (clr) transformation was then performed on the MoCoh-corrected $\mu$-XRF intensities, such that $I_{c l r}=\ln (I / G)$, where $I$ is the intensity of the element transformed, and $\mathrm{G}$ is geometric mean of all the elements analyzed at the same measuring point. We analyzed a set of selected elements that had sufficient counts, and that are important in ecosystem and weathering processes. Although the investigated elements are found in various compounds in the sediment, they can indicate three types of processes: allochthonous, biogenic, and authigenic (Lopez et al. 2006). We used Ticlr and $\mathrm{K}_{c l r}$ as indicative of detrital input, Siclr and Caclr as indicative of detrital input, as well as biogenic silica and calcite formation respectively, and $\mathrm{Fe}_{\mathrm{clr}}, \mathrm{Mn}_{\mathrm{clr}}$, and $\mathrm{S}_{\mathrm{clr}}$ as indicative in part of detrital input, as well as redox processes. 
To better trace these additional processes, MoCoh standardized values were then divided by Ti counts to obtain a measure of silicate weathering (K/Ti), biogenic silica ( $\mathrm{Si} / \mathrm{Ti}$ ), and authigenic mineral precipitation (Ca/Ti, Fe/Ti, Mn/Ti, and S/Ti). While none of these elements should be interpreted as uniformly indicating a single process, their variability as assemblages may lead to an improved understanding of lake sedimentation (Martin-Puertas et al., 2017). In conjunction with other proxies, elemental assemblages can be used to assess catchment inputs (both lithological and organic), redox conditions, and potentially aquatic primary productivity. Elemental concentrations are sometimes non-linearly correlated with XRF intensities throughout sediment cores, due to matrix effects, physical properties, and geometry of the sample in different sections. To avoid such effects, we resort to using log-ratios of $\mu$-XRF intensities, which are linear functions of log ratios of element concentrations (Weltje and Tjallingii 2008). The log-ratio transformation also helps with issues related to closed-sum data encountered in multivariate statistical analyses (Martin-Puertas et al., 2017).

\subsection{Stable isotope analysis}

Organic carbon $(\mathrm{C})$ and nitrogen $(\mathrm{N})$ concentrations and standard isotopic ratios $\left(\delta^{13} \mathrm{C}, \delta^{15} \mathrm{~N}\right)$ were measured on dried bulk sediment samples every $10 \mathrm{~cm}$ for the Fox Lake sediment core and every $5 \mathrm{~cm}$ for the Devils Lake sediment cores. Analyses were conducted at the Stable Isotope Mass Spectrometry Laboratory at Kansas State University and the Central Appalachian Stable Isotope Facility at the University of Maryland following standard procedures for sediment samples. To maximize precision, in-house standards calibrated to PeeDee Belemnite $\left(\delta^{13} \mathrm{C}\right)$ and atmospheric $\mathrm{N}_{2}$ gas $\left(\delta^{15} \mathrm{~N}\right)$ were used. Analytical error was better than $0.1 \%$ for $\delta^{13} \mathrm{C}$ and better than $0.2 \%$ for $\delta^{15} \mathrm{~N}$. C: $\mathrm{N}$ ratio of the bulk sediment was calculated by dividing $\% \mathrm{C}$ by $\% \mathrm{~N}$.

\subsection{Particle size analysis}

Bulk sedimentary particle size was measured for Fox Lake sediments because of an expectation that particle size would change during the Holocene as aridity and eolian inputs changed. We did not measure particle size with this method at Devils Lake because of the nature of the sedimentary material and difficulty in interpreting bulk particle size in this depositional environment. Throughout the 9.3-m Fox Lake sediment core, $1 \mathrm{~mL}$ samples were removed from every third centimeter. Each sample was pretreated with $30 \mathrm{~mL}$ of $25 \% \mathrm{H}_{2} \mathrm{O}_{2}$ at $80{ }^{\circ} \mathrm{C}$ to remove organic matter. After settling overnight, excess liquid was decanted. Samples were measured using a laser particle size analyzer through a wet dispersion unit (Mastersizer 3000 and Hydro EV accessory; Malvern Instruments Ltd., Worcestershire, UK). The analyzer outputted volume percentages for 100 size classes from 0.01 to $3500 \mu \mathrm{m}$. Volume percentages from these size classes were summed according to USDA grain size categories: clay $<2 \mu \mathrm{m}$, silt 2-50 $\mu \mathrm{m}$, sand $50-2000 \mu \mathrm{m}$, and gravel $>2000 \mu \mathrm{m}$. While most sediments are finer-grained than soils, we used the USDA classification to match interpretations of particle size transport. 


\subsection{Magnetic parameters and unmixing model}

To gain insight into sediment dynamics at Devils Lake we calculated the fluxes of lithogenic (LITH), pedogenic (PED), and biogenic (BIO) magnetic minerals using the method developed by Lascu et al. (2010). For this we measured anhysteretic remanent magnetization (ARM), saturation magnetization $\left(M_{s}\right)$, and saturation remanent magnetization ( $\mathrm{Mrs}_{\mathrm{rs}}$ ) at the Institute for Rock Magnetism, University of Minnesota. A D-Tech 2000 demagnetizer was used for the acquisition of ARM in a $0.1 \mathrm{mT}$ direct field superimposed on an alternating frequency field decaying at a rate of $5 \mu \mathrm{T}$ per half cycle from a peak value of $200 \mathrm{mT}$. ARM susceptibility ( $\chi_{\text {ARM }}$ ) was calculated by dividing the ARM to the direct field. Remanence measurements were performed using a $2 \mathrm{G}$ superconducting rock magnetometer. $\mathrm{M}_{\mathrm{s}}$ and $\mathrm{M}_{\mathrm{rs}}$ were obtained from slope-corrected hysteresis loops measured on a Princeton Measurements vibrating sample magnetometer using a maximum applied field of 1 $\mathrm{T}$ and a step size of $5 \mathrm{mT}$.

Using the unmixing model of Lascu et al. (2010), we derived relative abundances and fluxes of three magnetic components in the sediments from the magnetic measurements. The BIO, PED, and LITH components were determined to be the end members in the unmixing model, based on their distinct values for the ratios of $\mathrm{Mrs}_{\mathrm{rs}} / \mathrm{M}_{\mathrm{s}}$ and $\chi_{\mathrm{ARM}} / \mathrm{Mrs}_{\mathrm{rs}}$ (respectively 0.5 and $1.5 \mathrm{~mm} / \mathrm{A}$ for BIO; 0.2 and $0.01 \mathrm{~mm} / \mathrm{A}$ for PED; 0.05 and $0.01 \mathrm{~mm} / \mathrm{A}$ for LITH). The BIO end member represents a population of grains with narrow size range $(30-80 \mathrm{~nm})$ produced in the lake by magnetotactic bacteria, via controlled biomineralization of magnetite, a process that entails alignment of the nanocrystals in chains. After the death of the bacteria, these particles are preserved in the sediment as magnetofossils (either as linear or partially collapsed chains), and provide information about the physical and geochemical conditions in the lake. The PED end member originates in the catchment soils, as the result of magnetic enhancement either through abiotic precipitation, or induced biomineralization by dissimilatory iron-reducing bacteria. The pedogenic ensemble comprises clustered grains of magnetite ranging in size from a few nm to 1-2 $\mu \mathrm{m}$, and are transported to the lake by surface runoff. The LITH end member is representative of magnetic particles in the silt grain size range. The source of these larger particles is in the bedrock, and transport to the lake is accomplished by streams and/or overland flow. Fluxes of each end member were calculated as magnetite $\left(\mathrm{M}_{\mathrm{s}}=92 \mathrm{Am}^{2} / \mathrm{kg}\right)$ by multiplying the relative abundance by the fraction of dry sediment, gamma density from core logging, and sediment accumulation rate from the age model (Lascu et al. 2010). We did not measure magnetic properties of Fox Lake sediments with this method because of differences in parent material and associated uncertainties in interpretation of magnetic data.

\subsection{Multivariate statistics}

To investigate if the terrestrial biosphere determined the trajectory of elemental change, principal component analyses were performed on the eight elemental counts derived from XRF, as well as additional variables capturing different aspects of ecosystem history for Fox Lake and for Devils Lake. There were a total of 21 input 
variables for Devils Lake (Table 1) and 17 variables for Fox Lake (Table 2). The number of variables differed between the sites due to: (1) differences between magnetic and particle size parameters measured on the sediments of each lake, and (2) differences in the number of pollen variables required to summarize vegetation change between the grassland and forested sites. All variables for Fox Lake were measured on the 2012 core, and all variables for Devils Lake except for pollen were measured on the 2012 core. Pollen data were correlated to the 2012 core using the age model of Grimm et al. (2009) and the age model of Williams et al. (2015). The analyses were performed on the correlations because the units differed among the input variables, and data were statistically resampled to the lowest resolution by depth for all variables (every $5 \mathrm{~cm}$ for Devils Lake and every $10 \mathrm{~cm}$ for Fox Lake). Principal components were rotated to strengthen contrasts.

\section{Results}

\subsection{Sediment sources}

334 The source material analysis at the forested site (Devils Lake) is based on the 335 magnetic end member fluxes from the unmixing model, and the $\mathrm{C}: \mathrm{N}$ ratio (Fig. 2).

336 The non-biogenic magnetic material input changed over time, with gradual declines 337 in fluxes of both LITH and PED toward present, except for an increase in both 338 components between $\sim 5,000$ and 3,000 cal yBP. PED fluxes also increased between $339 \sim 9,000$ and $\sim 7,000$ cal yBP. Magnetofossil flux (BIO) was relatively constant for 340 most of the record, except in the sediments deposited during the past several 341 centuries, when the flux increased by an order of magnitude. The source of the 342 organic matter seems to be aquatic, as evidenced by $\mathrm{C}: \mathrm{N}$ values that rarely exceeded 34310 , the ratio found in aquatic microbes and algae.

Source material variability during the course of system development at the grassland site (Fox Lake) was evaluated via sediment grain size analyses and the C:N ratio (Fig. 3). Throughout the record, the flux of silt was dominant, with sand being secondary in importance. Comparatively, only very small amounts of clay were delivered to the sediments for most of the record. Two important shifts should be highlighted: (1) a striking increase in influx of sand-sized particles during the mid-Holocene around 5500 cal yBP (zone F3), and (2) an increase in clay and silt influx starting at 1,500 cal yBP (zone F1). The C:N ratio in Fox Lake was almost exclusively $>10$, indicating that the organic matter was mainly sourced within the catchment. The steady decline of $\mathrm{C}: \mathrm{N}$ values throughout the Holocene suggests either decreasing terrestrial plant inputs, or an increase in relative abundance of algae and aquatic bacteria (Fig. 3 ).

\subsection{Sediment geochemistry}

To study the sequence of ecosystem processes at each site, we examined temporal patterns of XRF-derived relative elemental abundance. At the forested site $\mathrm{Ti}$ clr, $\mathrm{K}_{\mathrm{clr}}$, Siclr, and Caclr were highest in zone D5, then declined during the Late Glacial, followed by relatively constant values throughout the Holocene, until $\sim 500$ cal yBP (Fig. 4a). Feclr, and $\mathrm{Mn}_{\mathrm{clr}}$ reached maxima in zone D4, before decreasing throughout the record starting with the Younger Dryas (ca. 12, 750 cal yBP) (Hughen et al. 
2000). $\mathrm{Ti}_{\mathrm{clr}}, \mathrm{K}_{\mathrm{clr}}, \mathrm{Si}_{\mathrm{clr}}, \mathrm{Ca}_{\mathrm{clr}}$, and $\mathrm{Fe}_{\mathrm{clr}}$ reached their Holocene maxima during the first part of the Holocene hypsithermal, between ca. 9,500 and 7,000 cal yBP (Dean et al. 1997). Sclr experienced a steady increase throughout the record. Element abundances increased in the last few centuries of the record (zone D1). Log ratios of Ti-normalized elemental counts are shown in Fig. 4b. Ln (K/Ti) and $\ln (\mathrm{Si} / \mathrm{Ti})$ demonstrated a pattern of decline toward present, with ln (K/Ti) exhibiting a stronger gradient across the Pleistocene-Holocene transition. $\mathrm{Ln}(\mathrm{Ca} / \mathrm{Ti})$ values were variable but high in zones D5 and D4, then underwent a sharp transition at $\sim 12,750$ cal yBP, followed by a decrease until 8,000 cal yBP. A local maximum between 8,000 and 7,000 cal yBP is followed by relatively constant values for the rest of the record. $\mathrm{Ln}(\mathrm{Fe} / \mathrm{Ti})$ and $\ln (\mathrm{Mn} / \mathrm{Ti})$ displayed increasing values until $\sim 9,000$ cal yBP, with local maxima in zones D5 (for Mn) and D4 (for Fe and Mn). Both $\ln (\mathrm{Fe} / \mathrm{Ti}$ ) and $\ln (\mathrm{Mn} / \mathrm{Ti})$ displayed pronounced maxima occurred during the Early Holocene ( 11,500-9,000 cal yBP). Ln(S/Ti) showed an oscillatory pattern but increased over time toward present

Relative elemental abundances in sediments from the grassland site demonstrated a similar pattern to those from the forested site during the Holocene. All seven selected elements demonstrated a long-term decline in abundance from the beginning of the record to present (Fig. 5). This was not a monotonic decline, however. During the early portion of the record (from 9,200 to $\sim 8,500$ cal yBP, zone F5), when Fox Lake was surrounded by oak woodland, abundances initially increased, with all elements, except for $S_{\text {clr, }}$ exhibiting the highest values in the record at the transition to grassland (ca. 8,500 cal yBP). Other notable peaks occurred in zone F4 ( $\left.\mathrm{Ca}_{c l r}, \mathrm{~S}_{\mathrm{clr}}\right)$ and around 4,000 cal yBP $\left(\mathrm{Ti}_{\mathrm{clr}}, \mathrm{K}_{\mathrm{clr}}, \mathrm{Si}_{\mathrm{clr}}, \mathrm{Ca}_{\mathrm{clr}}, \mathrm{Fe}_{\mathrm{clr}}\right.$, $\mathrm{S}_{\mathrm{clr}}$ ). Log ratios of Ti-normalized counts again revealed different patterns from the absolute counts, with $\ln (\mathrm{K} / \mathrm{Ti})$ and $\ln (\mathrm{Si} / \mathrm{Ti})$ declining, $\ln (\mathrm{Mn} / \mathrm{Ti})$ and $\ln (\mathrm{Fe} / \mathrm{Ti})$ increasing, and $\ln (\mathrm{S} / \mathrm{Ti})$ and $\ln (\mathrm{Ca} / \mathrm{Ti})$ exhibiting variable behavior, with midHolocene maxima.

Temporal changes in source material and geochemical structure of sediments can be analyzed with relationships among selected elements. At the forested site, there were positive correlations between $\mathrm{Si}_{\mathrm{clr}}$ and $\mathrm{K}_{\mathrm{clr}}(\mathrm{r}=0.91), \mathrm{K}_{\mathrm{clr}}$ and $\mathrm{Fe}_{\mathrm{clr}}(\mathrm{r}=0.66)$, $\mathrm{Mn}_{\mathrm{clr}}$ and $\mathrm{Fe}_{\mathrm{clr}}(\mathrm{r}=0.77)$, and $\mathrm{Ca}_{\mathrm{clr}}$ and $\mathrm{Sr}_{\mathrm{clr}}(\mathrm{r}=0.76)$, although the correlation strength varied with time (Fig. 6). Slope changes, such as the ones observed in the $\mathrm{K}_{\mathrm{clr}}-\mathrm{Fe}_{\mathrm{clr}}$ or $\mathrm{Ca}_{\text {clr }}-\mathrm{Sr}_{\mathrm{clr}}$ biplots, indicate temporal variability in geochemical processes.

Relationships among elemental counts at the grassland site showed similar positive correlations (Fig. 7), which were very strong throughout the entire record for Siclr and $K_{c l r}(r=0.97)$, and $K_{c l r}$ and $F_{\text {clr }}(r=0.96)$. These two relationships were linear with very little scatter, suggesting similar source material or processes throughout the history of sediment deposition. For $\mathrm{Mn}_{\mathrm{clr}}$ and $\mathrm{Fe}_{\mathrm{clr}}$, and for $\mathrm{Caclr}$ and $\mathrm{Sr}_{\mathrm{clr}}$ the correlation was still strong ( $\mathrm{r}=0.85$, and 0.81 respectively), but exhibiting more scatter.

\subsection{Principal component analyses}


At the forested site (Fig. 8), the first principal component, explaining $47.7 \%$ of the variability in the dataset, followed the stratigraphic trend that showed a major transition from minerogenic to organic-rich sediments after 13,000 cal yBP (D4-D3 transition). Samples with high values of elemental counts, LITH and PED fluxes, and Picea pollen loaded positively on the first principal component, while samples with high values of $\delta^{13} \mathrm{C}, \mathrm{C}$ and $\mathrm{N}$ concentrations, and Quercus pollen loaded negatively on the first principal component. The second principal component, explaining $16.1 \%$ of the variability, separated samples high in Ulmus pollen, charcoal and $\delta^{15} \mathrm{~N}$ from samples high in Poaceae pollen and S concentration.

At the grassland site (Fig. 9), the first principal component, explaining $34.8 \%$ of the variability in the dataset, displayed periods of little change (e.g., in zone F4), continual decrease (e.g., in zone F3) and continual increase (e.g., in zone F2). Samples with high values of elemental counts loaded positively on the first principal component, and samples with high values of $\delta^{15} \mathrm{~N}$ and sand loaded negatively on the first principal component. The second principal component, explaining $24.3 \%$ of the variability, separated samples high in arboreal pollen types and $\mathrm{C}$ and $\mathrm{N}$ concentrations from samples with high magnetic susceptibility, Mn concentrations, and $\delta^{13} \mathrm{C}$ values.

\section{Discussion}

4.1. How did source material change over time?

Source materials at both sites changed as evidenced in the sedimentary sequences. At Fox Lake, progressively lower values of C:N reflect gradually declining terrigenous organic inputs and a shift to a predominance of aquatic algal and bacterial organic matter. A similar pattern was observed at Deming Lake, $425 \mathrm{~km}$ to the north of Fox Lake (Fig. 1), with reduced fluxes of both terrestrial organic material and total sediment deposition over the entire 9,500 year sequence (McLauchlan et al. 2013). The mineral matter flux at Fox Lake increased over time, with the proportion of sand gradually decreasing (except for a transient increase between 5,500 and 4,000 cal yBP) in favor of silt and clay, especially for the last 1,500 years.

At Devils Lake, mineral sediment sources shifted from inputs from bedrock sources, as indicated by the pre-Holocene predominance of lithogenic magnetic particles, to catchment soils- and lake-derived material, reflected by increasing amounts of pedogenic and biogenic magnetic particles toward present. A noted exception was the increase of both PED and LITH fluxes during the mid Holocene, a warm and dry interval. Several sedimentary records in the region indicate increased eolian influx during this time, such as increased quartz inputs at Elk Lake, Minnesota (Dean 1997). Small inputs of calcareous loess have been noted at Devils Lake during the mid-Holocene from sources to the west (Grimm et al. 2009). While this would be barely detectable in XRF data as elevated Ca levels, magnetic parameters provide more detail about eolian inputs depending on the size of the wind-blown particles. If 454 they are in the very fine silt size range $(2-4 \mu \mathrm{m})$, they contribute to the PED 
component, whereas if they are larger they contribute to LITH fluxes. Abrupt increases in sand influx beginning at $5500 \mathrm{cal}$ yBP at Fox Lake reflected the proximity to dune fields to the south that mobilized around the same time during increased aridity (Miao et al. 2006).

\subsection{What were the nutrient patterns during Holocene ecosystem development?}

While different lengths of time are represented in the records presented here9200 years for Fox Lake and 17,000 years for Devils Lake- the similarity in geochemical patterns indicates that the sequence of processes may be the same across sites although the rate of these processes may vary. Temporal patterns of accumulation of nutrients in the sediments, especially nitrogen and base cations, during Holocene ecosystem development indicate striking secular trends. One of the strongest patterns in these records is the slow decline in elemental abundances toward present, reflecting some kind of ontogenetic process or combination of processes. This is especially interesting given the different lithologic settings of these two sites, and the relatively heterogeneous nature of glacial till present on both sites. Lakes in pure bedrock settings, especially basalt and granite with wellestablished weathering pathways, may demonstrate even clearer signals of geochemical change over time (Sperber et al. 2017, Burghelea et al. 2018)

Similar patterns-declines in concentrations of easily-weathered elements such as $\mathrm{Ca}$ and $\mathrm{Sr}$-have been documented in late-Pleistocene and Holocene sedimentary records in the Alps (Koinig et al. 2003, Schmidt et al. 2006) and the southern Urals (Maslennikova et al. 2016). Clear signals of $\mathrm{N}$ accumulation as seen in chronosequences (Engstrom et al. 2000, Wardle et al. 2004) and some lake sedimentary sequences (Hu et al. 2001, McLauchlan et al. 2013) are also seen at Fox Lake in sedimentary $\delta^{15} \mathrm{~N}$ (Fig. 3). An increase in $\delta^{15} \mathrm{~N}$ values at the beginning of the sedimentary record was not as clear at Devils Lake, possibly due to climatic control of $\mathrm{N}$ fluxes to the basin during ice sheet retreat and very early landscape evolution (Williams et al., 2015). It is possible that additional factors confound interpretation of $\delta^{15} \mathrm{~N}$ values as indicating early successional processes, however.

The relationships between elements show dominantly, but not entirely, abiotic control of elemental ratios. At Fox Lake, $\mathrm{K}_{\mathrm{clr}}$ and $\mathrm{Ca}_{\mathrm{clr}}$ both decline from 8,000 years ago toward present, a time period when grassland vegetation stayed relatively constant (Fig. 5). Si, K, Ti, and Ca abundances in Devils Lake show similar decreasing trends over the first 7,000 years of the record. In the bedrock present at this site, $\mathrm{K}$ and $\mathrm{Ca}$ are found in extremely low concentrations as the Baraboo quartzite is both chemically and physically mature (Medaris et al., 2003). The quartzite and the claystone and siltstone layers interspersed within the quartzite are composed of $\mathrm{Si}$, $\mathrm{Ti}, \mathrm{Al}$, and Fe (Medaris et al., 2003). Early inputs of $\mathrm{K}$ and Ca to Devils Lake may have been either from unstable, sparsely vegetated local catchment sources deposited by the retreating glacier, which have subsequently been eroded or chemically weathered, or increased eolian deposition due to drier conditions. Maximum $\mathrm{K}$ and Ca abundances in Devils Lake between 9,500 and 7,000 cal yBP are more difficult to 
500 interpret, as they occur in the middle of zone D3 when vegetation composition is 501 fairly stable. Subsequent stabilization of the catchment has reduced clastic input in

In Devils Lake zone D4, $\ln (\mathrm{Ca} / \mathrm{Ti})$ increased, in contrast to $\ln (\mathrm{K} / \mathrm{Ti})$ and $\ln (\mathrm{Si} / \mathrm{Ti})$, which coincided with peaks in $\ln (\mathrm{Mn} / \mathrm{Ti}), \ln (\mathrm{Fe} / \mathrm{Ti})$, and $\ln (\mathrm{S} / \mathrm{Ti})$. These patterns in ratios could be related to a shift to endogenic mineral precipitation, likely due to a change in the redox state of the lake waters in response to climate change during the Late Glacial interstadial. During this time period dark, banded microbial sediments were accumulating in deep, stratified lake waters characterized by bottom anoxia (Williams et al., 2015). Ln(Ca/Ti) decreased suddenly with abrupt cooling at the onset of the Younger Dryas. Throughout the record, the decline in $\ln (\mathrm{Si} / \mathrm{Ti})$ lagged behind $\ln (\mathrm{K} / \mathrm{Ti})$, which in turn lagged behind the decline in $\ln (\mathrm{Ca} / \mathrm{Ti})$, as Ca is more easily mobilized than $\mathrm{K}$ during chemical weathering, and $\mathrm{Si}$ is the least prone to be dissolved (Nesbitt et al. 1996). $\mathrm{Ln}(\mathrm{Si} / \mathrm{Ti}$ ) was high at the beginning of the record and decreased afterward, suggesting that initial inputs of lithogenic silica from the catchment during glacial retreat were extremely high. As the catchment stabilized, physical weathering decreased and detrital input decreased. Peaks in $\ln (\mathrm{Si} / \mathrm{Ti})$ at $\sim 9,500 \mathrm{cal}$ yBP and to a lesser extent at $\sim 6,500$ cal yBP, may suggest increased contributions from biogenic silica at those times. Despite the appearance of diatoms and corresponding in-lake productivity around 7,500 cal yBP, biogenic silica inputs were not as large as the previous high input of detrital silica.

$\mathrm{Fe}$ is correlated to both $\mathrm{K}$ and Ti throughout the record at both sites, suggesting that Fe in the lake sediments is mainly detrital. However, there are time periods characterized by weaker correlation between $\mathrm{Fe}$ and $\mathrm{K}$, and $\mathrm{Fe}$ and $\mathrm{Ti}$, especially at the forested site. This points to a more important contribution from authigenic ironbearing minerals, meaning Fe entered the lake in dissolved form through groundwater and precipitated as iron oxides and/or hydroxides. High $\ln (\mathrm{Fe} / \mathrm{Ti})$ and $\ln (\mathrm{Mn} / \mathrm{Ti}$ ), along with abundant vivianite and pyrite in zone D4 (visually identified using petrography), suggest reducing conditions during the Late Glacial interstadial (Williams et al., 2015). At the grassland site, the $S$ trend corelates with those of the other elements, suggesting an origin from sulfates in the calcareous tills from the catchment (Gorham et al., 1983). At the forested site, S has an opposite trend to the other elements, suggesting it is associated with organic matter, which increases steadily throughout the record (Williams et al., 2015).

The Ca-Sr relationship provides additional information about the source material. Concentrations of $\mathrm{Ca}$ and $\mathrm{Sr}$ in the Baraboo quartzite are extremely low (Medaris et al., 2003), while the till around Fox Lake is calcareous (Commerford et al., 2016). Sr often substitutes for Ca in calcium-bearing minerals and is equally mobile during chemical weathering. At Fox Lake, $\ln (\mathrm{Ca} / \mathrm{Sr})$ is higher during the oak woodland phase prior to 8,200 cal yBP and lower during the grassland phase after 8,200 cal yBP. At Devils Lake, $\ln (\mathrm{Ca} / \mathrm{Sr})$ is high prior to 12,800 cal yBP and low and relatively constant from 12,800 cal yBP to present (Fig. 6). Strong correlation between Ca and $\mathrm{Sr}$ indicates a single source for both elements, while a weaker correlation suggests 
separate provenance, e.g., Ca from an endogenic source and $\mathrm{Sr}$ from a lithogenic source.

Climate conditions-hydrologic changes in the catchment, lake level, and evaporation - were considered in other studies to strongly influence elemental concentrations of same seven elements that we studied here (Martin-Puertas et al. 2011, Heymann et al. 2013). Lithological composition and mineralogy (quartz silicates, clay silicates, calcite, coarse particles) have also been considered the dominant factor in determining sedimentary elemental concentrations (Koinig et al. 2003). Declines in elemental concentration could be simply reflecting depletion of mobile elements such as $\mathrm{Ca}$ and $\mathrm{K}$ from source material in the catchment (Minyuk et al. 2014). In addition to simple first order hydrologic dissolution, there could be a change in the pace of chemical or physical weathering, or changes in transport pathways similar to those observed in Glacier Bay, Alaska during ecosystem development (Milner et al. 2007). Recently, a unified "erosion signal" has been identified in alpine lake sediments characterized by changes in elemental concentrations (Arnaud et al. 2016). In lacustrine settings, Ti is considered a metric of detrital input, so a decline in Ti concentration as observed at both sites in this study likely indicates a gradual decline in detrital input. Finally, there could be further influences through the mechanism by which elements are precipitated in sediments and diagenetic alteration.

\subsection{Biosphere-lithosphere interactions: Did vegetation determine the trajectory of elemental change at each site?}

After initial establishment of vegetation at each site, comparisons of vegetation and geochemical change between sites indicate a limited role of vegetation change in influencing geochemical parameters at each site. This generally agrees with other studies that attribute changes in element concentrations in sediment cores to climate-driven changes in weathering and transport processes. An alternative possibility is sediment geochemical change should be attributed to climate-driven vegetation change and subsequent changes in biogeochemical cycling (MartinPuertas et al., 2017). In our study, at both the grassland site and the forested site, the first principal component separated samples with high elemental abundances from those with high organic matter concentration. At the forested site, high Picea pollen loaded positively on the first axis with the elemental counts, and Quercus pollen loaded with organic matter, but this is difficult to interpret purely as a vegetation signal due to a simultaneously warming climate. Thus, there was some correlation of elemental change and forest composition (either hardwood or coniferous forest), but there was also concurrent climate change occurring over the intervals with changes in forest composition.

The other vegetation transitions later in the Holocene at the forested site (involving Ulmus) are only correlated with $\delta^{15} \mathrm{~N}$, which indicates strong links between vegetation and $\mathrm{N}$ cycling throughout the record. Arboreal pollen at Fox Lake and Poaceae (non-arboreal pollen) at Devils Lake loaded in the opposite direction from the $\mathrm{N}$ cycling proxy $\delta^{15} \mathrm{~N}$ at both sites. Early Holocene vegetation reorganization and 
development of the lake catchment played dominant roles in sediment deposition at Lake Meerfelder Maar, Germany (Martin-Puertas et al., 2017). Interactions among vegetation types were important during the transition from glacial to interglacial conditions at the Gerzensee site in Switzerland (Ammann et al. 2013), but this may be a due to the relatively large magnitude of vegetation change as indicated in pollen assemblages.

The degree of vegetation change in this study, while notable at each site, is not as large as those demonstrated to causes geochemical changes in other sequences

601 between glacial and interglacial conditions. In particular, differences in primary 602 productivity during stadial-interstadial cycles caused changes in weathering rates at 603 Les Échets, France (Kylander et al. 2011) and Lake El'gygytgyn, Russia (Minyuk et al. 604 2014). The onset of aquatic productivity and organic matter deposition was 605 certainly important at Devils Lake, resulting in anoxic conditions and notable black 606 bands dominated by amorphous aquatic organic material in the sediments

607 (Williams et al., 2015). However, while the rate of declining elemental 608 concentrations was altered significantly by this one transition from glacial to 609 interglacial conditions, the direction of the trajectory was the same across the 610 transition, indicating a more complex set of processes in addition to plant 611 colonization of a bare landscape. In early succession on recently deglaciated terrain, 612 the timing of establishment of certain plant functional types such as $\mathrm{N}_{2}$ fixers and 613 coniferous trees can have significant effects on accretion of soil $\mathrm{C}$ and $\mathrm{N}$, and erosion 614 rates (Crocker and Major 1955, Fastie 1995). At Devils Lake, the transition from 615 coniferous to deciduous forest in Zone D3 certainly affected fire regime, but not the 616 geochemistry based on the Ti-normalized element concentrations. Finally, 617 geochemical sedimentary records may be able to add detail to the classic view that 618 the relative importance of autogenic and allogenic processes changes over 619 successional time (Matthews, 1992).

621 Another way to assess the role of the terrestrial biosphere is to compare the 622 trajectories between the two sites. The similarities in the sequence of geochemical 623 changes between the forest and the grassland site provide further support for a 624 limited role of vegetation type. Comparisons of absolute rates of change are 625 complicated by different elemental counts between sites, but, for example, declines 626 in $\ln (\mathrm{K} / \mathrm{Ti})$ and $\ln (\mathrm{Ca} / \mathrm{Ti})$ seem to be faster at the forested site than at the grassland 627 site. However, differences in lithology, topography, and basin size could be more 628 important than vegetation differences between grassland and forest. In particular, 629 Fox Lake is larger and shallower, with calcareous glacial till as parent material and 630 significant agricultural land use in the watershed. Devils Lake is deeper, with non631 calcareous glacial till and Precambrian quartzite as parent material and a protected 632 watershed within a state park. As an alternative hypothesis, it is possible that 633 climate change was directly influencing geochemistry through catchment 634 weathering and hydrologic transport of material into the lake basin. Further 635 estimates of weathering rates, catchment destabilization due to aridity, or 636 hydrologic fluxes over Holocene timescales would help test these hypotheses. 


\section{Conclusions}

639 To assess rates, patterns, and mechanisms of ecosystem development after glacial 640 retreat, we compared two sedimentary sequences in the upper Midwestern U.S., one 641 from a grassland site and a forested site. We found that source material changed 642 over the Holocene sedimentary sequences. We also found that the patterns of 643 nutrients, especially limiting nutrients such as nitrogen, potassium, calcium, and 644 magnesium, changed over the Holocene sedimentary sequences. It seems that once 645 vegetation was established, there was minimal influence of vegetation composition 646 on inorganic sediment properties thereafter. At the forested site, transitions among 647 vegetation from Picea to Pinus to deciduous hardwood led to changes in fire regime 648 and nutrient cycling but not inorganic element abundances. At the grassland site, 649 the transition from oak forest to grassland affected primarily delivery of organic 650 material to the catchment. There is future potential to interpret sedimentary 651 elemental concentrations in light of ecological processes. Two aspects are likely to 652 make these successful: (1) comparing several sites with different vegetation 653 histories, and (2) measuring many proxies to help provide independent estimates of 654 multiple processes influencing sediment records.

\section{Acknowledgments}

657 We thank J. Mueller, S. McConaghy, J. Commerford, A. Myrbo, K. Brady, A. Lingwall, T. 658 Ocheltree, R. Paulman, and R. Keen for field and laboratory assistance. J. L. Morris 659 provided helpful discussion about the Fox Lake XRF data. We thank Catherine Yansa 660 and an anonymous reviewer for comments that greatly improved the manuscript. 661 Financial support was provided by National Science Foundation BCS-0955225 to 662 K.M. and a Kansas State University College of Arts and Sciences Undergraduate 663 Scholarship to R.S. Support for I.L. was provided through ERC grant 320750 under 664 the European Union's Seventh Framework Programme (FP/2007-2013)

\section{Author contributions} 669 primary data from Fox Lake and/or Devils Lake sediment cores, and all authors 670 discussed results and contributed to manuscript preparation. 
673 Table 1. Proxy variables for various ecosystem processes, measured on sediment 674 cores from the grassland and forested lakes and presented in this manuscript.

675 Original sources for some of the proxy variables shown in this manuscript are also 676 reported here.

677

678

\begin{tabular}{|l|l|l|}
\hline & $\begin{array}{l}\text { Fox Lake } \\
\text { (grassland site) }\end{array}$ & $\begin{array}{l}\text { Devils Lake } \\
\text { (forested site) }\end{array}$ \\
\hline charcoal concentrations & Commerford et al. 2015 & Williams et al. 2015 \\
\hline pollen concentrations & Commerford et al. 2015 & Maher 1982 \\
\hline $\begin{array}{l}\text { elemental concentrations } \\
(\mathrm{XRF})\end{array}$ & this manuscript & this manuscript \\
\hline$\% \mathrm{C}, \% \mathrm{~N}, \delta^{13} \mathrm{C}, \delta^{15} \mathrm{~N}$ & this manuscript & Williams et al. 2015 \\
\hline $\begin{array}{l}\text { magnetic parameters to } \\
\text { estimate particle size }\end{array}$ & & this manuscript \\
\hline $\begin{array}{l}\text { laser-based particle size } \\
\text { analysis }\end{array}$ & this manuscript & \\
\hline
\end{tabular}

679

680 
Table 2. The 21 input variables for the principal component analysis of the Devils Lake sediment core, and eigenvectors for each variable on the first two principal components.

686

687

\begin{tabular}{|l|c|c|}
\hline & Principal component 1 & Principal component 2 \\
\hline charcoal count & 0.17 & 0.63 \\
\hline $\mathrm{Ca}$ & 0.92 & -0.24 \\
\hline $\mathrm{Sr}$ & 0.62 & -0.50 \\
\hline $\mathrm{K}$ & 0.91 & -0.22 \\
\hline $\mathrm{Fe}$ & 0.67 & 0.12 \\
\hline $\mathrm{Mn}$ & 0.85 & 0.16 \\
\hline $\mathrm{Si}$ & 0.87 & 0.07 \\
\hline $\mathrm{S}$ & -0.15 & -0.56 \\
\hline $\mathrm{Ti}$ & 0.76 & -0.35 \\
\hline$\delta^{15} \mathrm{~N}$ & 0.13 & 0.86 \\
\hline $\mathrm{N}(\%)$ & -0.89 & -0.23 \\
\hline$\delta^{13} \mathrm{C}$ & -0.73 & -0.31 \\
\hline $\mathrm{C}(\%)$ & -0.90 & -0.07 \\
\hline Flux LITH $\left(\mu \mathrm{g} \mathrm{cm}^{-2} \mathrm{yr}^{-1}\right)$ & 0.77 & -0.24 \\
\hline Flux PED $\left(\mu \mathrm{gm}^{-2} \mathrm{yr}^{-1}\right)$ & 0.69 & -0.23 \\
\hline Flux BIO $\left(\mu \mathrm{gm}^{-2} \mathrm{yr}^{-1}\right)$ & 0.11 & -0.18 \\
\hline Flux total ferrimagnetic & & \\
$\left(\mu \mathrm{g} \mathrm{cm}{ }^{-2} \mathrm{yr}^{-1}\right)$ & 0.78 & -0.25 \\
\hline Picea & 0.87 & -0.18 \\
\hline Quercus & -0.83 & -0.32 \\
\hline Ulmus & -0.13 & 0.78 \\
\hline Poaceae & 0.33 & -0.54 \\
\hline
\end{tabular}


689 Table 3. The 17 input variables for the principal component analysis of the Fox Lake 690 sediment core, and eigenvectors for each variable on the first two principal 691 components.

692

693

\begin{tabular}{|l|c|c|}
\hline & Principal Component 1 & Principal Component 2 \\
\hline $\begin{array}{l}\text { Magnetic susceptibility } \\
(\mathrm{SI})\end{array}$ & 0.06 & 0.83 \\
\hline Arboreal pollen (\%) & 0.17 & -0.57 \\
\hline flux clay $\left.\mathrm{mg} \mathrm{cm}^{-2} \mathrm{yr}^{-1}\right)$ & 0.37 & -0.34 \\
\hline flux sand $\left.\mathrm{mg} \mathrm{cm}^{-2} \mathrm{yr}^{-1}\right)$ & -0.15 & -0.17 \\
\hline$\delta^{15} \mathrm{~N}$ & -0.40 & -0.05 \\
\hline $\mathrm{N}(\%)$ & 0.40 & -0.78 \\
\hline$\delta^{13} \mathrm{C}$ & -0.40 & 0.82 \\
\hline $\mathrm{C}(\%)$ & 0.30 & -0.76 \\
\hline $\mathrm{Ca}$ & 0.85 & -0.13 \\
\hline $\mathrm{Sr}$ & 0.88 & -0.16 \\
\hline $\mathrm{K}$ & 0.93 & -0.20 \\
\hline $\mathrm{Fe}$ & 0.78 & -0.30 \\
\hline $\mathrm{Mn}$ & 0.49 & 0.70 \\
\hline $\mathrm{Si}$ & 0.88 & -0.24 \\
\hline $\mathrm{S}$ & 0.65 & -0.50 \\
\hline $\mathrm{Ti}$ & 0.85 & -0.24 \\
\hline charcoal count & 0.15 & -0.29 \\
\hline
\end{tabular}

694

695

696 
Figure 1. a) Regional map with locations of Fox Lake, Devils Lake, and the other sites referred to in text (Deming Lake, Elk Lake). b) Detail of Fox Lake basin morphology and vegetation. c) Detail of Devils Lake basin morphology and vegetation. Red dots represent coring sites.

Figure 2. Source material of sediments at the forested site (Devils Lake, Wisconsin): fluxes of biogenic (BIO), pedogenic (PED), and lithogenic (LITH) ferrimagnetic material calculated from measured magnetic parameters, $\mathrm{N}$ and $\mathrm{C}$ isotopic composition, and C:N ratio of organic material, and relative abundances of main pollen types. Zones (D1-D5) were based on lithologic transitions in the sediment core identified by Williams et al. (2015)

Figure 3. Source material of sediments at the grassland site (Fox Lake, Minnesota): fluxes of clay, silt, and sand, $\mathrm{N}$ and $\mathrm{C}$ isotopic composition, and the $\mathrm{C}$ : $\mathrm{N}$ ratio of organic material, and relative abundance of arboreal pollen. Zones (F1-F5) were based on magnetic susceptibility transitions in the sediment core identified by Commerford et al. (2016).

Figure 4. Centered-log ratios of selected elements (a) and log ratios of element intensities with respect to the intensity of Ti (b) for sediments from the forested site 719 (Devils Lake, Wisconsin).

Figure 5. Centered-log ratios of selected elements (a) and log ratios of element intensities with respect to the intensity of $\mathrm{Ti}$ (b) for sediments from the grassland site (Fox Lake, Minnesota).

Figure 6. Cross plots of selected element abundances from the sedimentary sequence at the forested site (Devils Lake, Wisconsin) color coded by time.

Figure 7. Cross plots of selected element abundances from the sedimentary sequence at the grassland site (Fox Lake, Minnesota) color coded by time.

Figure 8. Principal components analysis of 21 variables measured on a sediment core spanning the entire sequence of ecosystem development following deglaciation $\sim 17,000$ years ago from Devils Lake, Wisconsin. a) Time series of principal components 1 and 2; b) Score plot of principal components 1 and 2: circles represent data points and diamonds represent eigenvectors for each of the variables.

Figure 9. Principal components analysis of 17 variables measured on a sediment core spanning 9200 years of ecosystem development following deglaciation from Fox Lake, Minnesota. a) Time series of principal components 1 and 2; b) Score plot

742 represent eigenvectors for each of the variables. 
Ammann, B., U. J. van Raden, J. Schwander, U. Eicher, A. Gilli, S. M. Bernasconi, J. F. N. van Leeuwen, H. Lischke, S. J. Brooks, O. Heiri, K. Novakova, M. van Hardenbroek, U. von Grafenstein, S. Belmecheri, W. O. van der Knaap, M. Magny, W. Eugster, D. Colombaroli, E. Nielsen, W. Tinner, and H. E. Wright. 2013. Responses to rapid warming at Termination 1 a at Gerzensee (Central Europe): Primary succession, albedo, soils, lake development, and ecological interactions. Palaeogeography Palaeoclimatology Palaeoecology 391:111131.

Arnaud, F., J. Poulenard, C. Giguet-Covex, B. Wilhelm, S. Revillon, J. P. Jenny, M. Revel, D. Enters, M. Bajard, L. Fouinat, E. Doyen, A. Simonneau, C. Pignol, E. Chapron, B. Vanniere, and P. Sabatier. 2016. Erosion under climate and human pressures: An alpine lake sediment perspective. Quaternary Science Reviews 152:1-18.

Attig, J. W., P. R. Hanson, J. E. Rawling, A. R. Young, and E. C. Carson. 2011. Optical ages indicate the southwestern margin of the Green Bay Lobe in Wisconsin, USA, was at its maximum extent until about 18,500 years ago. Geomorphology 130:384-390.

Boyle, J. F. 2007. Loss of apatite caused irreversible early-Holocene lake acidification. Holocene 17:543-547.

Buma, B., S. Bisbing, J. Krapek, and G. Wright. 2017. A foundation of ecology rediscovered: 100years of succession on the William S. Cooper plots in Glacier Bay, Alaska. Ecology 98:1513-1523.

Burghelea, C. I., K. Dontsova, D. G. Zaharescu, R. M. Maier, T. Huxman, M. K. Amistadi, E. Hunt, and J. Chorover. 2018. Trace element mobilization during incipient bioweathering of four rock types. Geochimica Et Cosmochimica Acta 234:98114.

Colombaroli, D., and D. G. Gavin. 2010. Highly episodic fire and erosion regime over the past 2,000 y in the Siskiyou Mountains, Oregon. Proceedings of the National Academy of Sciences of the United States of America 107:1890918914.

Commerford, J. L., B. Leys, J. R. Mueller, and K. K. McLauchlan. 2016. Great Plains vegetation dynamics in response to fire and climatic fluctuations during the Holocene at Fox Lake, Minnesota (U.S.A.). Holocene 26:302-313.

Crocker, R. L., and J. Major. 1955. Soil development in relation to vegetation and surface age at Glacier Bay, Alaska. Journal of Ecology 43:427-448.

Cutler, N. A., L. R. Belyea, and A. J. Dugmore. 2008. The spatiotemporal dynamics of a primary succession. Journal of Ecology 96:231-246.

Dean, W. E. 1997. Rates, timing, and cyclicity of Holocene eolian activity in northcentral United States: Evidence from varved lake sediments. Geology 25:331334.

Engstrom, D. R., S. C. Fritz, J. E. Almendinger, and S. Juggins. 2000. Chemical and biological trends during lake evolution in recently deglaciated terrain. Nature 408:161-166. 
Engstrom, D. R., and B. C. S. Hansen. 1985. Postglacial vegetational change and soil development in southeastern Labrador as inferred from pollen and chemical stratigraphy. Canadian Journal of Botany 63:543-561.

Fastie, C. L. 1995. Causes and ecosystem consequences of multiple pathways of primary succession at Glacier Bay, Alaska. Ecology 76:1899-1916.

Ford, M. S. 1990. A 10,000 year history of natural ecosystem acidification. Ecological Monographs 60:57- 89.

Gorham, E., W. E. Dean, and J. E. Sanger. 1983. The chemical composition of lakes in the North-Central United-States. Limnology and Oceanography 28:287-301.

Grimm, E. C., L. J. Maher, and D. M. Nelson. 2009. The magnitude of error in conventional bulk-sediment radiocarbon dates from central North America. Quaternary Research 72:301-308.

Heymann, C., O. Nelle, W. Dorfler, H. Zagana, N. Nowaczyk, J. B. Xue, and I. Unkel. 2013. Late Glacial to mid-Holocene palaeoclimate development of Southern Greece inferred from the sediment sequence of Lake Stymphalia (NEPeloponnese). Quaternary International 302:42-60.

Hu, F. S., B. P. Finney, and L. B. Brubaker. 2001. Effects of Holocene Alnus expansion on aquatic productivity, nitrogen cycling, and soil development in southwestern Alaska. Ecosystems 4:358-368.

Koinig, K. A., W. Shotyk, A. F. Lotter, C. Ohlendorf, and M. Sturm. 2003. 9000 years of geochemical evolution of lithogenic major and trace elements in the sediment of an alpine lake - the role of climate, vegetation, and land-use history. Journal of Paleolimnology 30:307-320.

Küchler, A. W. 1964. Potential natural vegetation of the conterminous United States. Pages 89-92 The national atlas of the United States of America. U.S. Geological Survey, Washington, DC.

Kylander, M. E., L. Ampel, B. Wohlfarth, and D. Veres. 2011. High-resolution X-ray fluorescence core scanning analysis of Les Echets (France) sedimentary sequence: new insights from chemical proxies. Journal of Quaternary Science 26:109-117.

Lascu, I., S. K. Banerjee, and T. S. Berquo. 2010. Quantifying the concentration of ferrimagnetic particles in sediments using rock magnetic methods. Geochemistry Geophysics Geosystems 11:22.

Lopez, P., E. Navarro, R. Marce, J. Ordoñez, L. Caputo, and J. Armengol. 2006. Elemental ratios in sediments as indicators of ecological processes in Spanish reservoirs. Limnetica 25:499-512.

Lusardi, B. A., C. E. Jennings, and K. L. Harris. 2011. Provenance of Des Moines lobe till records ice-stream catchment evolution during Laurentide deglaciation. Boreas 40:585-597.

Mackereth, F. J. H. 1966. Some chemical observations on post-glacial lake sediments. Philosophical Transactions of the Royal Society B-Biological Sciences 250:165-213.

Maher, L. J. 1982. The palynology of Devils Lake, Sauk County, WI. . Quaternary History of the Driftless Area. University of Wisconsin Extension, Geological and Natural History Survey, Madison, Wisconsin. 
Martin-Puertas, C., B. L. Valero-Garces, M. P. Mata, A. Moreno, S. Giralt, F. MartinezRuiz, and F. J. Jimenez-Espejo. 2011. Geochemical processes in a Mediterranean Lake: a high-resolution study of the last 4,000 years in Zoar Lake, southern Spain. Journal of Paleolimnology 46:405-421.

Maslennikova, A. V., V. N. Udachin, and P. G. Aminov. 2016. Lateglacial and Holocene environmental changes in the Southern Urals reflected in palynological, geochemical and diatom records from the Lake Syrytkul sediments. Quaternary International 420:65-75.

McLauchlan, K. K., I. Lascu, A. Myrbo, and P. R. Leavitt. 2013. Variable ecosystem response to climate change during the Holocene in northern Minnesota, USA. Geological Society of America Bulletin 125:445-452.

Miao, X., J. A. Mason, J. B. Swinehart, D. B. Loope, P. R. Hanson, R. J. Goble, and X. Liu. 2006. A 10,000 year record of dune activity, dust storms, and severe drought in the central Great Plains. Geology 35:119-122.

Milner, A. M., C. L. Fastie, I. Chapin F S, D. R. Engstrom, and L. C. Sharman. 2007. Interactions and linkages among ecosystems during landscape evolution. Bioscience 57:237-247.

Minyuk, P. S., V. Y. Borkhodoev, and V. Wennrich. 2014. Inorganic geochemistry data from Lake El'gygytgyn sediments: marine isotope stages 6-11. Climate of the Past 10:467-485.

Nesbitt, H. W., G. M. Young, S. M. McLennan, and R. R. Keays. 1996. Effects of chemical weathering and sorting on the petrogenesis of siliciclastic sediments, with implications for provenance studies. Journal of Geology 104:525-542.

Norton, S. A., R. H. Perry, J. E. Saros, G. L. Jacobson, I. J. Fernandez, J. Kopacek, T. A. Wilson, and M. D. SanClements. 2011. The controls on phosphorus availability in a Boreal lake ecosystem since deglaciation. Journal of Paleolimnology 46:107-122.

Pennington, W. M. T., E. Y. Haworth, A. P. Bonny, and J. P. Lishman. 1972. Lake sediments in northern Scotland. Philosophical Transactions of the Royal Society B-Biological Sciences 264:191-294.

Schmidt, R., C. Kamenik, R. Tessadri, and K. A. Koinig. 2006. Climatic changes from 12,000 to 4,000 years ago in the Austrian Central Alps tracked by sedimentological and biological proxies of a lake sediment core. Journal of Paleolimnology 35:491-505.

Sperber, C., O. A. Chadwick, K. L. Casciotti, K. G. Peay, C. A. Francis, A. E. Kim, and P. M. Vitousek. 2017. Controls of nitrogen cycling evaluated along a wellcharacterized climate gradient. Ecology 98:1117-1129.

U.S. Department of Agriculture. Natural Resources Conservation Service. "Soil Survey | NRCS Soils," www.nrcs.usda.gov/wps/portal/nrcs/main/soils/survey/.

US Department of Commerce, and NOAA. NWS Forecast Office. NOAA's National Weather Service, www.weather.gov/.

Wardle, D. A., L. R. Walker, and R. D. Bardgett. 2004. Ecosystem properties and forest decline in contrasting long-term chronosequences. Science 305:509513. 
878 Weltje, G. J., and R. Tjallingii. 2008. Calibration of XRF core scanners for quantitative 879 geochemical logging of sediment cores: Theory and application. Earth and $880 \quad$ Planetary Science Letters 274:423-438.

881 Williams, J. J., K. K. McLauchlan, J. R. Mueller, E. M. Mellicant, A. E. Myrbo, and I. Lascu. 2015. Ecosystem development following deglaciation: a new sedimentary record from Devils Lake, Wisconsin, USA. . Quaternary Science 885 Reviews 125:131-143. 